\title{
Implementasi Algoritma Naive Bayes Classifier Untuk Penentuan Kelayakan Penerima Beasiswa Peningkatan Prestasi Akademik (PPA) Bagi Mahasiswa
}

\author{
Edy Prabowo ${ }^{1}$, Abd. Charis Fauzan ${ }^{2, *}$ \\ Program Studi Ilmu Komputer, Universitas Nahdlatul Ulama Blitar, Indonesia. \\ 1edhy58641@gmail.com; 2abdcharis@unublitar.ac.id \\ *corresponding author
}

INFO ARTIKEL

Sejarah Artikel

Diterima: 5 Juli 2021

Direvisi: 25 Agustus 2021

Diterbitkan: 31 Agustus 2021

Kata Kunci

Naive bayes classifier

Kelayakan Beasiswa

Beasiswa PPA

\section{ABSTRAK}

Penentuan kelayakan penerima beasiswa peningkatan prestasi akademik (PPA) harus dilakukan secara objektif bagi mahasiswa, sebagai tuntutan untuk meningkatkan mutu prodi, perguruan tinggi serta kualitas mahasiswanya. Penelitian ini bertujuan untuk mengimplementasikan algoritma naive bayes classifier untuk penentuan kelayakan penerima beasiswa PPA. Data yang digunakan adalah 225 dataset mahasiswa di Prodi Ilmu Komputer Universitas Nahdlatul Ulama Blitar, yang terbagi atas 150 data latih dan 75 data uji. Dataset pada penelitian ini menggunakan dua atribut sebagai indikator kelayakan beasiswa PPA, yakni IPK Semester 1 dan IPK Semester 2. Sementara itu, kelas pada dataset terdiri atas kelas "layak" dan "tidak layak". Metode penelitian dilakukan dengan pengambilan dataset, pre-processing dataset, hingga implementasi naive bayes classifier pada sistem yang dikembangkan berbasis desktop menggunakan Pemrograman Java. Evaluasi sistem penentuan kelayakan mahasiswa menunjukkan hasil akurasi sebesar $92 \%$, presisi sebesar $98 \%$ dan recall sebesar $92,3 \%$.

\section{PENDAHULUAN}

Salah satu faktor yang mendukung sumber daya manusia yang berkualitas adalah pendidikan formal. Melalui dunia pendidikan, diharapkan kemampuan berpikir dan kecerdasan seseorang dapat dikembangkan agar mampu memanfaatkan dan mengolah sumber daya yang tersedia [1]. Setiap perguruan tinggi khususnya universitas memiliki banyak sekali program kerja yang ditawarkan bagi mahasiswa, salah satunya adalah program beasiswa peningkatan prestasi akademik, atau dikenal sebagai beasiswa PPA. Beasiswa PPA ini terserap hingga unit terkecil dalam perguruan tinggi, yakni program studi. Program ini diadakan untuk membantu meringankan beban mahasiswa selama menjalani masa studinya khususnya masalah biaya [2]. Penentuan kelayakan penerima beasiswa PPA harus dilakukan secara objektif bagi mahasiswa, sebagai tuntutan untuk meningkatkan mutu prodi, perguruan tinggi serta kualitas mahasiswanya. Oleh karena itu, diperlukan studi kasus berupa program studi yang memiliki aktivitas nyata dalam pemberian beasiswa PPA sebagai dataset dalam penelitian ini. Studi kasus yang ditentukan adalah Prodi Ilmu Komputer, Universitas Nahdlatul Ulama Blitar (UNU Blitar).

Universitas Nahdlatul Ulama Blitar (UNU Blitar) sebagai salah satu perguruan tinggi swasta, menyediakan beasiswa PPA bagi mahasiswa, baik yang berprestasi maupun yang kurang mampu. Pemberian Beasiswa PPA di UNU Blitar didistribusikan ke mahasiswa berdasarkan prodi masing-masing, salah satunya Prodi Ilmu Komputer. Proses pemberian beasiswa PPA di UNU Blitar pada umumnya dan di Prodi Ilmu Komputer pada khususnya, mengalami kendala dalam proses pengelompokan mahasiswa yang layak untuk 
mendapatkan beasiswa PPA. Hal ini terjadi karena proses penilaian yang tidak selalu diputuskan berdasarkan perhitungan yang pasti dan kriteria-kriteria yang telah ditetapkan universitas. Oleh karenanya, penentuan kelayakan penerima beasiswa PPA dengan pendekatan komputasi mutlak diperlukan demi terselenggaranya proses penerimaan beasiswa PPA dengan penilaian yang objektif [3].

Di sisi lain, kemampuan komputasi untuk mengumpulkan, menganalisis, meringkas, dan mengekstrak pengetahuan dari data jauh melampaui kemampuan manusia. Salah satu metode komputasi yang dapat digunakan sebagai algoritma untuk penentuan kelayakan penerima beasiswa PPA adalah naïve bayes classifier, yaitu metode yang dapat mengklasifikasikan data [4]. Metode ini dipilih karena algoritma ini memiliki tingkat keakuratan yang cukup tinggi. Metode nä̈ve bayes classifier merupakan bagian dari teknik probabilitas mampu menangani masalah ketidakpastian yang terjadi dalam kehidupan sehari-hari, dengan menekankan pada konsep probabilitas hipotesis dan evidance pada Naïve Bayes [5]. Naïve Bayes berasumsi bahwa efek dari suatu pada kelas yang diberikan adalah independen terhadap nilai atribut yang lainnya. Asumsi ini biasa disebut dengan class conditional inedepndence. Itu dibuat untuk menyederhanakan komputasi yang terkait dan dalam hal ini disebut sebagai "naïve". Naïve bayes classifier merupakan sebuah pengklasifikasian probabilitas sederhana yang mengaplikasikan Teorema Bayes dengan asumsi ketidak tergantungan (independent) yang tinggi [6]. Keuntungan penggunaan naive bayes classifier adalah metode ini hanya membutuhkan jumlah data pelatihan (training data) yang kecil untuk menentukan estimasi parameter yang diperlukan dalam proses pengklasifikasian. Naïve Bayes adalah model penyederhanaan dari metode bayes, Naïve Bayes inilah yang digunakan di dalam machine learning sebagai metode untuk mendapatkan hipotesis untuk suatu keputusan [7]. Berdasarkan latar belakang yang telah diuraikan, penelitian ini mengimplementasikan algoritma naive bayes classifier untuk penentuan kelayakan penerima beasiswa peningkatan prestasi akademik (PPA) bagi mahasiswa di Prodi Ilmu Komputer Universitas Nahdlatul Ulama Blitar

\section{METODE}

Dalam penelitian ini diperlukan langkah-langkah ilmiah untuk mendapatkan hasil yang maksimal. Untuk itu penulis merencanakan suatu langkah-langkah yang dapat memaksimalkan dalam penelitian ini. Langkah-langkah itu adalah sebagai berikut:

\section{Studi Literatur}

Studi literatur dilakukan dengan cara pencarian literatur, referensi, dan tutorial tentang Naïve Bayes Classifier dan semua materi yang berhubungan dengan masalah yang akan dibahas berupa buku dan artikel ilmiah.

\section{Pengumpulan Dataset}

Penelitian ini menggunakan dataset mahasiswa Prodi Ilmu Komputer UNU Blitar yang diperoleh dari Pusat Teknologi Informasi UNU Blitar. Dataset dibatasi hanya pada mahasiswa Prodi Ilmu Komputer UNU Blitar Semester 4 sebanyak 225 dataset. Dataset tersebut dibagi menjadi data latih sebanyak 150 dan data uji sebanyak 75 data.

\section{Pre-Processing}

Dataset yang telah didabatkan dibagi menjadi data latih sebanyak 150 dan data uji sebanyak 75 data. Kemudian dilakukan langkah pendahuluan sebelum dijadikan masukan di sistem naive bayes classifier, yakni pre-processing. Pre-processing dilakukan untuk memastikan bahwa dataset yang digunakan, baik data latih maupun data uji dapat diproses dengan baik oleh algoritma tanpa terjadi system error. Dataset yang telah didapatkan 
memiliki dua atribut dan dua kelas. Adapun atribut berupa nim dan nama hanyalah atribut pendukung yang tidak dilakukan pre-processing. Dua atribut utama adalah IPK Semester 1 (IPK 1) dan IPK Semester 2 (IPK 2). Atribut IPK 1 dan IPK 2 ditetapkan sebagai indikator penentuan beasiswa PPA di UNU Blitar. Sedangkan dua kelas tersebut adalah layak dan tidak layak untuk mendapatkan beasiswa PPA. Pre-processing dilakukan dengan cara mengubah atribut IPK 1 dan IPK 2 yang sebelumnya bersifat numerikal menjadi kategorikal. Hal ini dilakukan untuk menyederhanakan masukan dalam naive bayes classifier. Cara yang dilakukan untuk mengubah IPK numerikal ke kategorikal adalah membuat kategori "Baik" dan "Cukup" dalam mendefinisikan IPK. Jika IPK kurang dari 3.00 maka dikategorikan "Cukup", sedangkan jika IPK lebih dari sama dengan 3.00 maka dikategorikan "Baik". Tabel 1 menunjukkan sampel dataset yang akan dilakukan preprocessing. Untuk selanjutnya, nilai dari atribut IPK 1 dan IPK 2 akan berganti menjadi kategorikal.

Tabel 1. Sampel pre-processing dataset

\begin{tabular}{|l|l|c|c|c|c|l|}
\hline \multicolumn{1}{|c|}{ Nama } & IPK 1 & Kategori 1 & IPK 2 & $\begin{array}{c}\text { Kategori } \\
\mathbf{2}\end{array}$ & Kelayakan \\
\hline 1955201001 & MUHAMMAD THOYIB & 3.44 & Baik & 3.30 & baik & layak \\
\hline 1955201002 & YOGA AGUNG DWI CAHYONO & 3.39 & Baik & 3.24 & baik & layak \\
\hline 1955201003 & HAMDUN NAJIB & 3.35 & Baik & 3.20 & baik & layak \\
\hline 1955201004 & HILAL MALAKA & 3.20 & Baik & 2.11 & cukup & tidak layak \\
\hline 1955201005 & PUJI LAKSONO & 3.59 & Baik & 3.28 & baik & layak \\
\hline 1955201006 & FANI HADI MAULANA & 1.73 & Cukup & 0 & cukup & tidak layak \\
\hline 1955201007 & IRWAN LESTARI & 3.39 & Baik & 3.25 & baik & layak \\
\hline 1955201008 & SOFI KURNIAWAN KHOTIR AL MALAK & 3.22 & Baik & 0 & cukup & tidak layak \\
\hline 1955201009 & FANI KURNIAWAN & 3.38 & Baik & 2.23 & cukup & tidak layak \\
\hline 1955201010 & MUTIARA SHEILA PUTRI & 3.56 & Baik & 2.30 & cukup & tidak layak \\
\hline 1955201011 & MOHAMAD JABAR YUSUF AZIZ & 3.56 & Baik & 3.69 & baik & layak \\
\hline 1955201012 & MIFTAHUL HUDA & 3.50 & Baik & 3.63 & baik & layak \\
\hline 1955201013 & NURUL HIDAYATI ASRORI & 3.42 & Baik & 3.15 & baik & layak \\
\hline 1955201015 & FARID IMTINANUL AMJAD & 3.32 & Baik & 3.15 & baik & layak \\
\hline 1955201016 & FEBBI SENA LESTARI & 3.68 & Baik & 3.90 & baik & layak \\
\hline 1955201017 & AHMAD NOOR FAUZAN & 2.92 & Cukup & 2.43 & cukup & tidak layak \\
\hline
\end{tabular}

\section{Implementasi Sistem.}

Penelitian ini mengimplementasikan sistem menggunakan perkakas bantu Netbeans 8.2 berbasiskan pemrograman java. Gambar 1 menunjukkan diagram alir (flowchart) dari sistem yang diimplementasikan. Mengacu Gambar 1, sistem dimulai dengan masukan berupa atribut calon penerima beasiswa berdasarkan dataset yang telah dikumpulkan. Atribut terdiri atas atribut utama dan pendukung. Adapun atribut utama adalah IPK 1 dan IPK 2 sedangkan atribut pendukung adalah nim dan nama. Atribut tersebut secara keseluruhan terhimpun dalam 150 dataset yang dijadikan data latih, serta 75 dataset sebagai data uji. Sebagai pembeda, 150 data latih memiliki atribut sekaligus kelas, sedangakn 75 data uji hanya memiliki atribut. Penentuan kelas pada data uji dilakukan oleh sistem. 


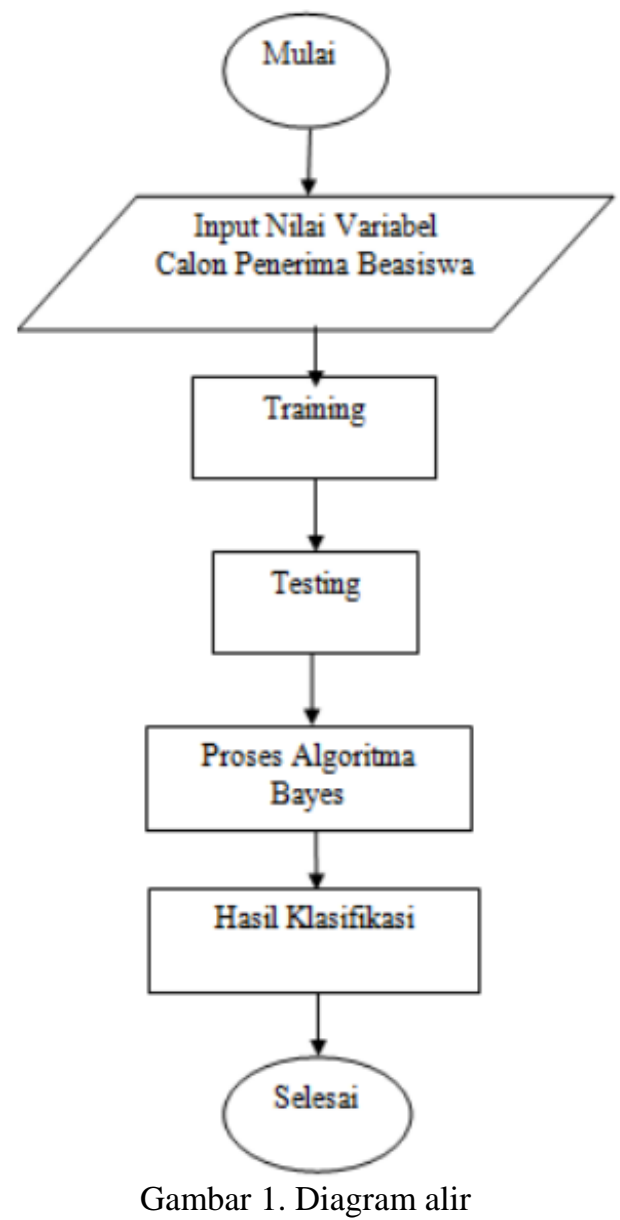

Selanjutnya, data latih dan data uji dihitung menggunakan algoritma Naive bayes classifier. Algoritma ini merupakan salah satu metode pembelajaran terawasi (supervised learning) yang memanfaatkan perhitungan probabilitas dan statistik yang dikemukakan oleh ilmuan Inggris bernama Thomas Bayes, yaitu memprediksi probabilitas di masa depan berdasarkan pengalaman di masa sebelumnya [5]. Sebagaimana pada Pangaribuan [7], perhitungan naive bayes classifier secara umum ditunjukkan melalui Persamaan 1 :

$$
P(H \mid X)=\frac{P(X \mid H)}{P(X)} \cdot P(H)
$$

Keterangan
$\mathrm{X}$
: Data dengan class yang belum diketahui
$\mathrm{H}$
: Hipotesis data merupakan suatu class spesifik
$\mathrm{P}(\mathrm{H} \mid \mathrm{X}) \quad$ : Probabilitas hipotesis $\mathrm{H}$ berdasar kondisi $\mathrm{X}$ (posteriori probabilitas)
$\mathrm{P}(\mathrm{H}) \quad$ : Probabilitas hipotesis $\mathrm{H}$ (prior probabilitas)
$\mathrm{P}(\mathrm{X} \mid \mathrm{H}) \quad$ : Probabilitas $\mathrm{X}$ berdasarkan kondisi pada hipotesis $\mathrm{H}$
$\mathrm{P}(\mathrm{X}) \quad$ : Probabilitas $\mathrm{X}$

\section{Evaluasi Sistem}

Evaluasi sistem pada penelitian ini menggunakan Confusion Matrix. Confusion Matrix berbentuk tabel matriks yang menggambarkan kinerja model klasifikasi pada serangkaian data uji yang nilai sebenarnya telah diketahui. Confusion Matrix memiliki 4 kombinasi nilai prediksi dan nilai aktual yang berbeda. Tabel 1 menunjukkan 4 kombinasi 
Confusion Matrix yang mana TP (True Positif) merupakan data yang diprediksi positif benar, TN (True Negatif) adalah data negatif yang diprediksi benar, FP (False Positif) adalah data negatif yang diprediksi positif, dan FN (False Negatif) adalah data positif yang diprediksi negatif [3].

Tabel 1. Confusion Matrix

\begin{tabular}{|c|c|}
\hline TP & FP \\
\hline FN & TN \\
\hline
\end{tabular}

Dari hasil data uji yang dilakukan, maka dapat dihitung performa dengan Confusion Matrix yaitu Accuracy, Precision, dan Recall/Sensitivity.

\section{a. Accuracy}

Accuracy adalah tingkat kedekatan nilai prediksi dengan nilai yang sebenarnya [8]. Accuracy dapat menjawab pertanyaan "Berapa persen mahasiswa yang benar ditentukan layak beasiswa PPA maupun tidak layak?”. Accuracy dapat dihitung dengan Persamaan 3.

$$
\text { Accuracy }=\frac{T P+T N}{T P+F P+T N+F N}
$$

\section{b. Precission}

Precission adalah tingkat keakuratan antara data yang diminta dengan hasil prediksi yang diberikan oleh model [9]. Precission dapat menjawan pertanyaan "Berapa persen mahasiswa yang benar ditentukan layak besiswa PPA dari keseluruhan yang ditentukan layak?". Precission dapat dihitung menggunakan Persamaan 4.

$$
\text { Precission }=\frac{T P}{T P+F P}
$$

\section{c. Recall/Sensitivity}

Recall/Sensitivity adalah keberhasilan model dalam menentukan kembali sebuah informasi [10]. Recall dapat menjawab pertanyaan "berapa persen mahasiswa yang ditentukan layak beasiswa PPA dibandingkan dengan keseluruhan mahasiswa yang sebenarnya layak beasiswa PPA?". Recall/Sensitivity dapat dihitung dengan Persamaan 5.

$$
\text { Recall/Sensitivity }=\frac{T P}{T P+F N}
$$

\section{HASIL DAN PEMBAHASAN}

Sistem penentuan leyakan beasiswa PPA ini dikembangkan menggunakan aplikasi Netbeans 8.2 dan JDK 1.8.0. Sistem yang sudah selesai dibuat selanjutnya dilakukan pengujian terhadap keseluruhan data uji. Pada penelitian ini dilakukan uji coba menggunakan 150 data latih (67\%) dan 75 data uji (33\%).

\section{Preprocessing}

Tabel 2 menunjukkan sampel dataset berupa hasil dari pre-processing yang telah dilakukan. Untuk selanjutnya, nilai dari atribut IPK 1 dan IPK 2 berganti menjadi kategorikal. Tabel 2 sebagai hasil akhir dari pre-processing yang direncakan dalam metode penelitian, sebagaimana ditunjukkan pada Tabel 1. 
Tabel 2. Sampel hasil pre-processing dataset

\begin{tabular}{|c|l|c|c|l|}
\hline \multicolumn{1}{|c|}{ No. } & \multicolumn{1}{|c|}{ IPK 1} & IPK 2 & \multicolumn{1}{|l|}{ Kelayakan } \\
\hline 1955201001 & MUHAMMAD THOYIB & baik & baik & layak \\
\hline 1955201002 & YOGA AGUNG DWI CAHYONO & baik & baik & layak \\
\hline 1955201003 & HAMDUN NAJIB & baik & baik & layak \\
\hline 1955201004 & HILAL MALAKA & baik & cukup & tidak layak \\
\hline 1955201005 & PUJI LAKSONO & baik & baik & layak \\
\hline 1955201006 & FANI HADI MAULANA & cukup & cukup & tidak layak \\
\hline 1955201007 & IRWAN LESTARI & baik & baik & layak \\
\hline 1955201008 & SOFI KURNIAWAN KHOTIR AL MALAK & baik & cukup & tidak layak \\
\hline 1955201009 & FANI KURNIAWAN & baik & cukup & tidak layak \\
\hline 1955201010 & MUTIARA SHEILA PUTRI & baik & cukup & tidak layak \\
\hline 1955201011 & MOHAMAD JABAR YUSUF AZIZ & baik & baik & layak \\
\hline 1955201012 & MIFTAHUL HUDA & baik & baik & layak \\
\hline 1955201013 & NURUL HIDAYATI ASRORI & baik & baik & layak \\
\hline 1955201015 & FARID IMTINANUL AMJAD & baik & baik & layak \\
\hline 1955201016 & FEBBI SENA LESTARI & baik & baik & layak \\
\hline 1955201017 & AHMAD NOOR FAUZAN & cukup & cukup & tidak layak \\
\hline
\end{tabular}

\section{Implementasi Sistem}

Gambar 2 menunjukkan tampilan antar muka dari sistem yang telah dikembangkan. Sistem ini berbasiskan graphical user interface (GUI), sebagai ciri khas sistem desktop. Terlihat bahwa ketika sistem dijalankan, terdapat tiga proses utama yang ditunjukkan, Antara lain:

1. Tampil data latih sebanyak 150 data yang di-import dari excel. Ketika data latih ditampilkan, sistem secara otomatis memanggil atribut dan kelas pada data latih. Atribut yang diambil adalah IPK 1 dan IPK 2 berupa data kategorikal. Data kelas yang diambil juga berupa kategorikal, yakni "layak" dan "tidak layak". Data kelas dari data latih selanjutnya diproses menggunakan kode sumber yang ditunjukkan oleh Tabel 3. Sedangkan atribut IPK dan IPK 2 diolah mengunakan kode sumber pada Tabel 4 dan 5.

2. Tampil masukan data uji berupa pilihan radio button, yakni IPK 1 ("baik" atau "cukup") serta IPK 2 ("baik" atau "cukup"). Pada tahap ini, peneliti melakukan entri tiap data uji mengacu pada 75 data uji sebagaimana dijelaskan pada dataset maupun pre-processing.

3. Tampil hasil penentuan kelayakan beasiswa PPA menggunakan algoritma naive bayes classifier. Sistem menampilkan hasil akhir berupa kelas "layak" atau "tidak layak". Hasil itulah yang menjadi acuan penentuan kelayakan beasiswa berdasarkan metode. Setelah hasil akhir ditentukan, peneliti melakukan perekapan hasil penentuan kelayakan beasiswa PPA versi sistem dan versi data yang sebenarnya agar evaluasi bisa dilakukan, baik untuk akurasi, presisi dan recall. 


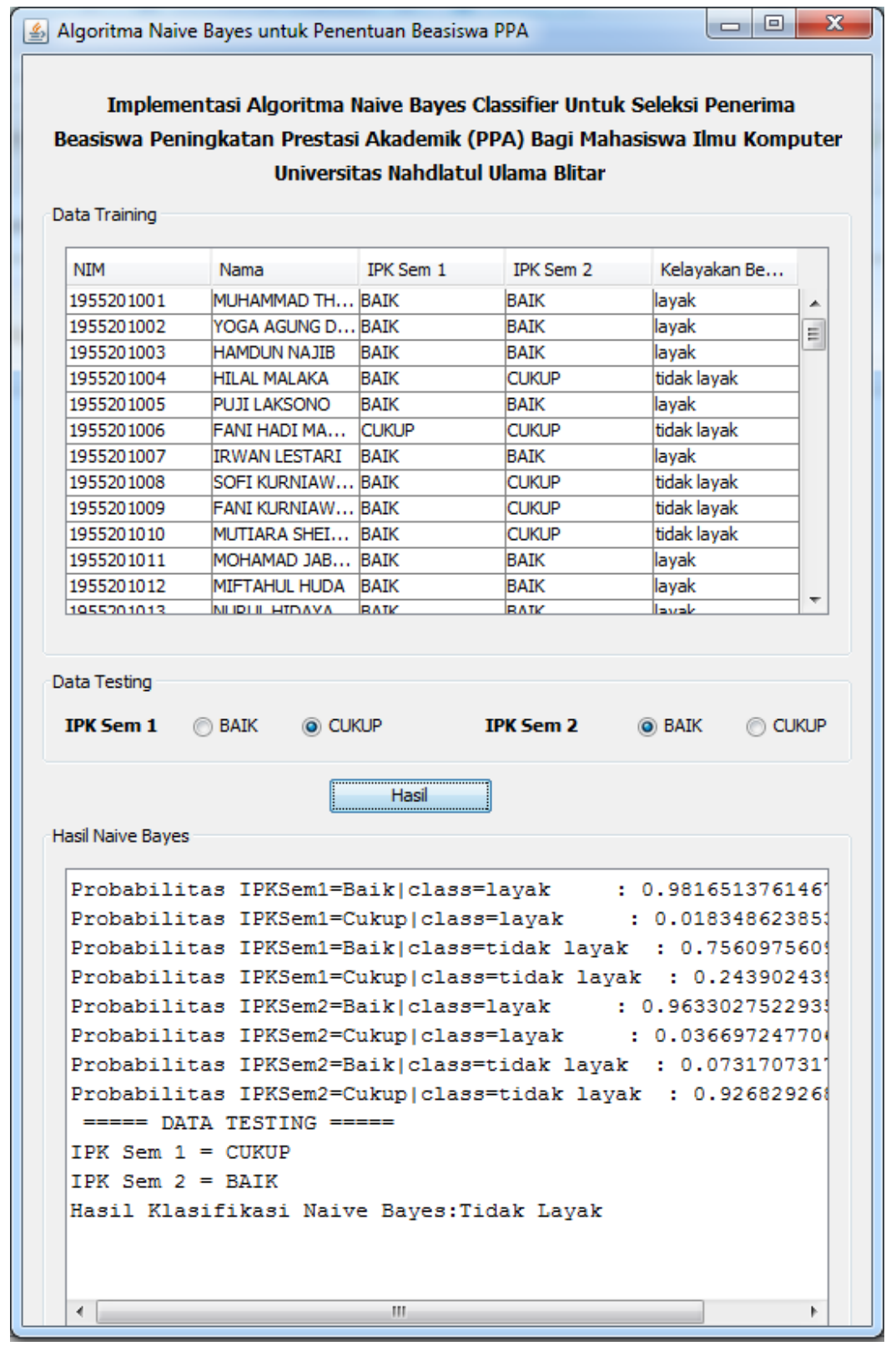

Gambar 2. Tampilan antar muka sistem

Tabel 3 adalah kode sumber untuk menghitung kelas "layak" maupun "tidak layak" yang didapatkan dari data latih. Dengan menggunakan kode sumber pada Tabel 3 didapatkan bahwa jumlah kelas "layak" pada data latih adalah 109 data dengan nilai probabilitas 0,727, sedangkan jumlah kelas "tidak layak" adalah 41 dengan nilai probabilitas adalah 0,273.

Tabel 3. Kode sumber untuk menghitung kelas layak dan kelas tidak layak

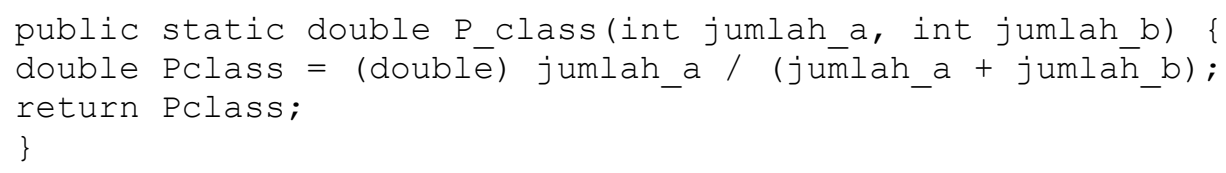

Tabel 4 adalah kode sumber untuk menghitung nilai probabilitas tiap nilai pada atribut IPK Semester 1 dengan tetap mengacu pada kelas "layak" atau "tidak layak". Perhitungan 
ini juga mengacu pada data latih sebagai runtutan proses setelah memproses kode sumber pada Tabel 3. Jadi, nilai probabilitas yang dihitung antara lain:

1. Nilai "baik" pada atribut IPK Semester 1 dengan kelas "layak" sejumlah 107 data dengan perolehan probabilitas sebesar 0,982.

2. Nilai "cukup" pada atribut IPK Semester 1 dengan kelas "layak" sejumlah 2 data dengan perolehan probabilitas sebesar 0,018 .

3. Nilai "baik" pada atribut IPK Semester 1 dengan kelas "tidak layak" sejumlah 31 data dengan perolehan probabilitas sebesar 0,756.

4. Nilai "cukup" pada atribut IPK Semester 1 dengan kelas "tidak layak" sejumlah 10 data dengan perolehan probabilitas sebesar 0,244.

Tabel 4. Kode sumber untuk menghitung probabilitas tiap nilai pada atribut IPK Semester 1

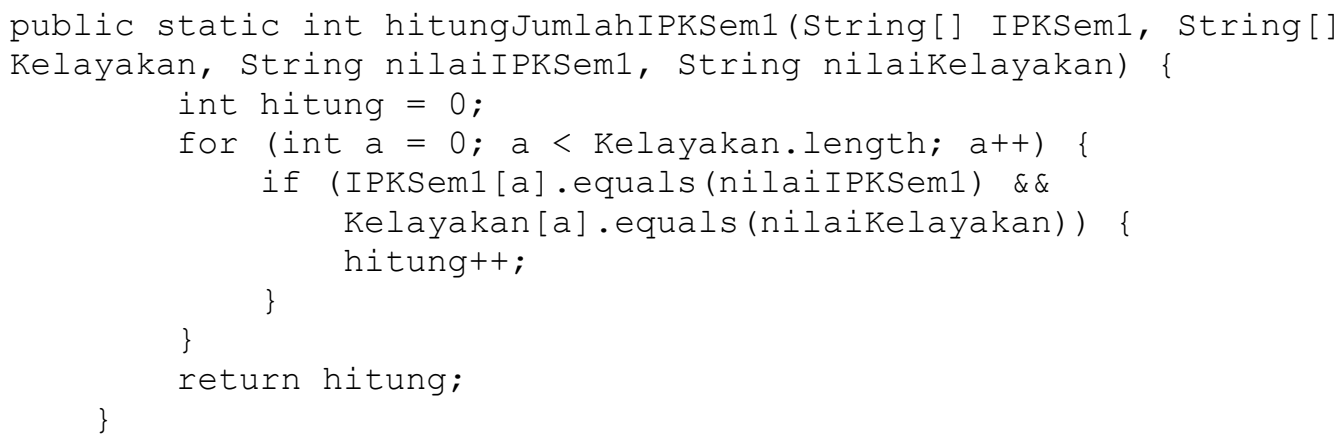

Tabel 5 adalah kode sumber untuk menghitung nilai probabilitas tiap nilai pada atribut IPK Semester 2 dengan tetap mengacu pada kelas "layak" atau "tidak layak". Perhitungan ini juga mengacu pada data latih sebagai runtutan proses setelah memproses kode sumber pada Tabel 4. Jadi, nilai probabilitas yang dihitung antara lain:

1. Nilai "baik" pada atribut IPK Semester 2 dengan kelas "layak" sejumlah 105 data dengan perolehan probabilitas sebesar 0,963.

2. Nilai "cukup" pada atribut IPK Semester 2 dengan kelas "layak" sejumlah 4 data dengan perolehan probabilitas sebesar 0,037.

3. Nilai "baik" pada atribut IPK Semester 2 dengan kelas "tidak layak" sejumlah 3 data dengan perolehan probabilitas sebesar 0,073.

4. Nilai "cukup" pada atribut IPK Semester 2 dengan kelas "tidak layak" sejumlah 38 data dengan perolehan probabilitas sebesar 0,927.

Tabel 5. Kode sumber untuk menghitung probabilitas tiap nilai pada atribut IPK Semester 2

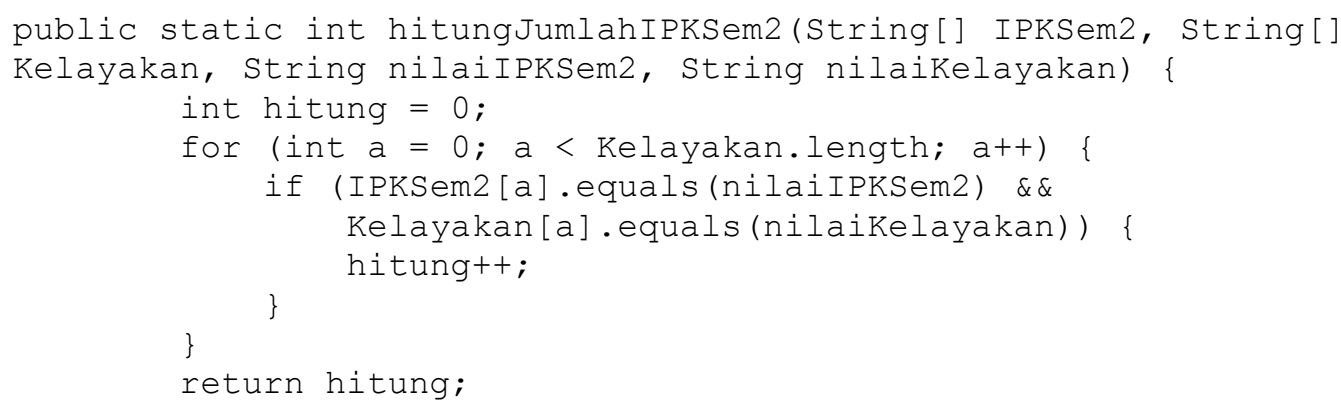


Hasil yang diperoleh dari kode sumber pada Tabel 3, 4 dan 5 secara otomatis membentuk model naive bayes classifier terhadap 150 data latih. Model tersebut digunakan ketika menguji satu per satu data uji dengan cara entri pada sistem. Pengujian dilakukan oleh peneliti berdasarkan acuan data uji sebanyak 75 data dengan tujuan untuk memperoleh penentuan kelayakan beasiswa PPA melalui sistem. Entri yang dilakukan oleh peneliti adalah memilih masukan nilai pada atribut IPK Semester 1 dan atribut IPK Semester 2 berupa nilai "baik" atau "cukup". Sehingga, probabilitas "layak" atau "tidak layak" dapat ditentukan menggunakan kode sumber pada Tabel 6.

Tabel 6. Kode sumber untuk menghitung probabilitas tiap nilai pada atribut IPK Semester 2

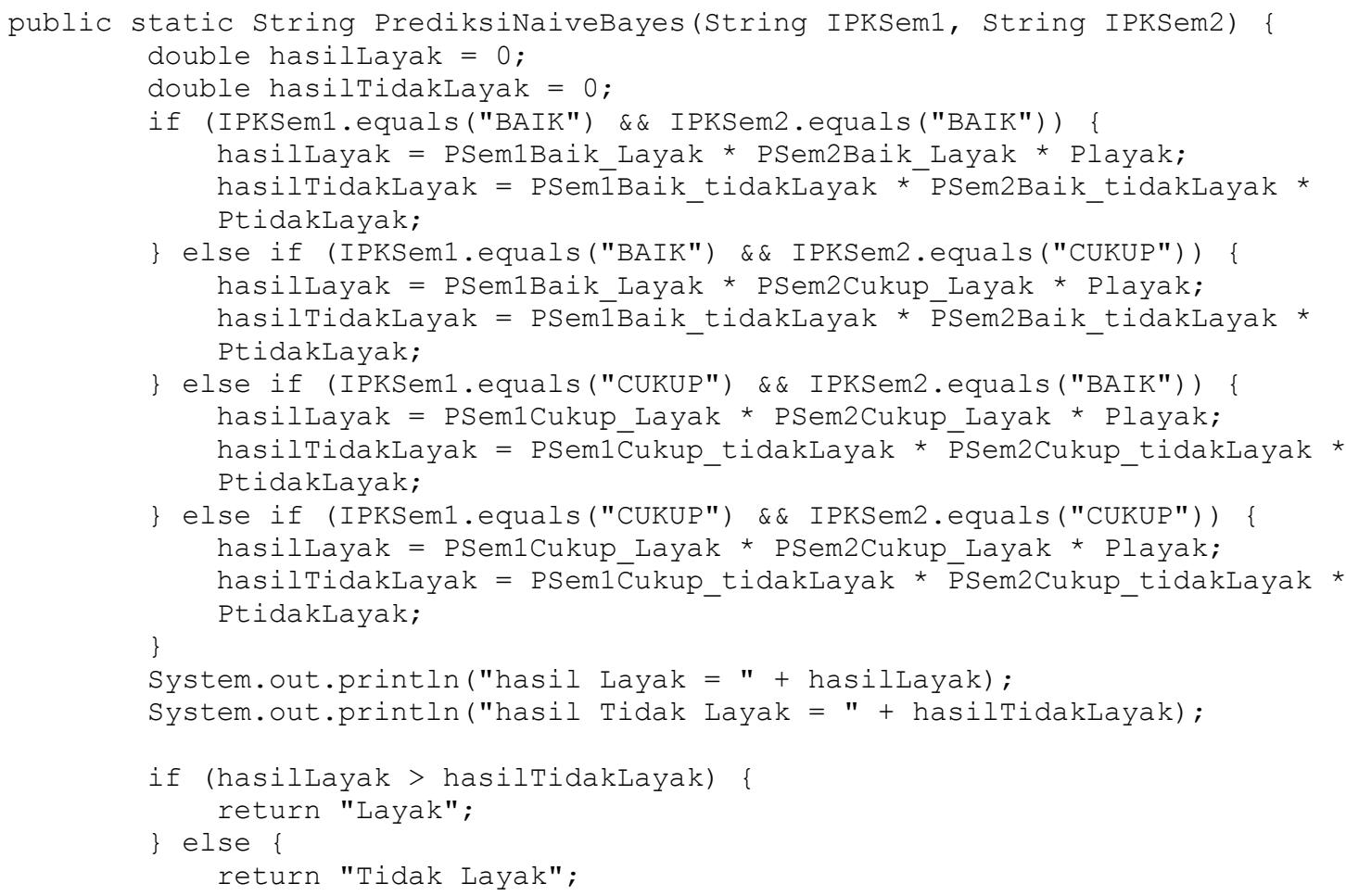

Probabilitas "layak" atau "tidak layak" ditentukan berdasarkan empat kemungkinan nilai atribut, antara lain:

1. Kemungkinan 1, jika atribut IPK Semester 1 bernilai "baik" dan atribut IPK Semester 2 juga bernilai "baik", maka probabilitas layak beasiswa PPA ditentukan dengan nilai probabilitas "baik" pada atribut IPK Semester 1 dengan kelas "layak" dikalikan dengan nilai probabilitas "baik" pada atribut IPK Semester 2 dengan kelas "layak" dikalikan juga dengan nilai probabilitas kelas "layak". Sedangkan, probabilitas tidak layak beasiswa PPA ditentukan dengan nilai probabilitas "baik" pada atribut IPK Semester 1 dengan kelas "tidak layak" dikalikan dengan nilai probabilitas "baik" pada atribut IPK Semester 2 dengan kelas "tidak layak" dikalikan juga dengan nilai probabilitas kelas "tidak layak".

2. Kemungkinan 2, jika atribut IPK Semester 1 bernilai "baik" dan atribut IPK Semester 2 bernilai "cukup", maka probabilitas layak beasiswa PPA ditentukan dengan nilai probabilitas "baik" pada atribut IPK Semester 1 dengan kelas "layak" dikalikan dengan nilai probabilitas "cukup" pada atribut IPK Semester 2 dengan kelas "layak" dikalikan juga dengan nilai probabilitas kelas "layak". Sedangkan, probabilitas tidak layak beasiswa PPA ditentukan dengan nilai probabilitas "baik" 
pada atribut IPK Semester 1 dengan kelas "tidak layak" dikalikan dengan nilai probabilitas "cukup" pada atribut IPK Semester 2 dengan kelas "tidak layak" dikalikan juga dengan nilai probabilitas kelas "tidak layak".

3. Kemungkinan 3, jika atribut IPK Semester 1 bernilai "cukup" dan atribut IPK Semester 2 bernilai "baik", maka probabilitas layak beasiswa PPA ditentukan dengan nilai probabilitas "cukup" pada atribut IPK Semester 1 dengan kelas "layak" dikalikan dengan nilai probabilitas "baik" pada atribut IPK Semester 2 dengan kelas "layak" dikalikan juga dengan nilai probabilitas kelas "layak". Sedangkan, probabilitas tidak layak beasiswa PPA ditentukan dengan nilai probabilitas "cukup" pada atribut IPK Semester 1 dengan kelas "tidak layak" dikalikan dengan nilai probabilitas "baik" pada atribut IPK Semester 2 dengan kelas "tidak layak" dikalikan juga dengan nilai probabilitas kelas "tidak layak".

4. Kemungkinan 4, adalah kemungkinan terakhir ditandai jika atribut IPK Semester 1 bernilai "cukup" dan atribut IPK Semester 2 juga bernilai "cukup", maka probabilitas layak beasiswa PPA ditentukan dengan nilai probabilitas "cukup" pada atribut IPK Semester 1 dengan kelas "layak" dikalikan dengan nilai probabilitas "cukup" pada atribut IPK Semester 2 dengan kelas "layak" dikalikan juga dengan nilai probabilitas kelas "layak". Sedangkan, probabilitas tidak layak beasiswa PPA ditentukan dengan nilai probabilitas "cukup" pada atribut IPK Semester 1 dengan kelas "tidak layak" dikalikan dengan nilai probabilitas "cukup" pada atribut IPK Semester 2 dengan kelas "tidak layak" dikalikan juga dengan nilai probabilitas kelas "tidak layak".

Jadi, nilai akhir antara probabilitas kelas "layak" maupun "tidak layak" beasiswa PPA pada kemungkinan 1, 2, 3 dan 4 selalu dibandingkan. Nilai probabilitas terbesar diantara keduanya menjadi acuan dalam penentuan beasiswa PPA versi algortima naive bayes classifier. Tabel 7 menunjukkan rekapitulasi penentuan beasiswa PPA pada 75 data uji. Tabel 7 menunjukkan perbandingan hasil penentuan beasiswa PPA antara kelas yang sebenarnya dengan kelas yang dihasilkan oleh sistem menggunakan algortima naive bayes classifier.

Tabel 7. Rekapitulasi penentuan beasiswa PPA pada data uji

\begin{tabular}{|c|c|c|c|c|c|c|}
\hline No. & NIM & Nama & IPK 1 & IPK 2 & \multicolumn{2}{|c|}{ Penentuan Beasiswa } \\
\cline { 5 - 6 } & 1955201207 & $\begin{array}{c}\text { MUHAMMAD ULUM } \\
\text { MUZAQI }\end{array}$ & Cukup & Cukup & tidak layak & tidak layak \\
\hline 2 & 1955201208 & MUHAMMAD KHAFIDZ & Baik & Cukup & Layak & Layak \\
\hline 3 & 1955201210 & NURUL KHODIJAH & Baik & Cukup & Layak & Layak \\
\hline 4 & 1955201211 & $\begin{array}{c}\text { MUHAMMAD SHUFFI } \\
\text { DZAR RIZQI }\end{array}$ & Baik & Cukup & Layak & Tidak Layak \\
\hline 5 & 1955201213 & $\begin{array}{c}\text { AHMAD TAMAMMUL } \\
\text { KHILQOH }\end{array}$ & Baik & Cukup & Layak & Tidak Layak \\
\hline 6 & 1955201214 & $\begin{array}{c}\text { MUHAMMAD } \\
\text { ALDIYANSYAH }\end{array}$ & Cukup & Cukup & tidak layak & tidak layak \\
\hline 7 & 1955201215 & FATIMATUS ZAHRO & Cukup & Cukup & tidak layak & tidak layak \\
\hline 8 & 1955201216 & $\begin{array}{c}\text { DIMAS ISBANDI DWI } \\
\text { KATMANTRI }\end{array}$ & Baik & Cukup & Layak & Tidak Layak \\
\hline 9 & 1955201217 & IRVAN JIHAD ALFIRDAUS & Baik & Cukup & Layak & Layak \\
\hline 10 & 1955201218 & IVA FIBRIANTI & Baik & Baik & Layak & Layak \\
\hline 11 & 1955201219 & AZIZAH NUR AINIYAH & Baik & Baik & Layak & Layak \\
\hline 12 & 1955201221 & SAFINATUR RIZQYYAH & Baik & Baik & Layak & Layak \\
\hline 13 & 1955201222 & AIL MAGHFIROH & Baik & Baik & Layak & Layak \\
\hline 14 & 1955201223 & $\begin{array}{c}\text { MUHAMMAD ALI } \\
\text { MUSABBIQIN }\end{array}$ & Baik & Baik & Layak & Layak \\
\hline 15 & 1955201224 & BAGUS ROCHMANSYAH & Cukup & Cukup & tidak layak & tidak layak \\
\hline 16 & 1955201228 & MOHAMMAD HASAN & Baik & Baik & Layak & Layak \\
\hline
\end{tabular}




\begin{tabular}{|c|c|c|c|c|c|c|}
\hline & & BISRI & & & & \\
\hline 17 & 1955201231 & MUHAMMAD FADHIL & Baik & Baik & Layak & Layak \\
\hline 18 & 1955201233 & ZAHROTUL ROFI'AH & Cukup & Cukup & tidak layak & tidak layak \\
\hline 19 & 1955201234 & KHOIRUR RIZAL & Baik & Baik & Layak & Layak \\
\hline 20 & 1955201235 & INA RUKYATUL KHOIROH & Baik & Baik & Layak & Layak \\
\hline 21 & 1955201238 & $\begin{array}{c}\text { NUR KHOIRILLAH } \\
\text { MAGHFIROH }\end{array}$ & Baik & Cukup & Layak & Layak \\
\hline 22 & 1955201239 & RIYAN ALWI MAULANA & Baik & Baik & Layak & Layak \\
\hline 23 & 1955201242 & ZANATIN ALIYAH & Baik & Baik & Layak & Layak \\
\hline 24 & 1955201245 & MIRZAH AMINULLOH & Baik & Baik & Layak & Layak \\
\hline 25 & 1955201246 & $\begin{array}{c}\text { ELITA 'AFIYATUS } \\
\text { SA'ADAH } \\
\end{array}$ & Baik & Baik & Layak & Layak \\
\hline 26 & 1955201248 & $\begin{array}{c}\text { PIPIT LAILATUL } \\
\text { RAHMANIA } \\
\end{array}$ & Baik & Baik & Layak & Layak \\
\hline 27 & 1955201251 & $\begin{array}{c}\text { MOCHAMMAD RONI } \\
\text { RAMADHAN } \\
\end{array}$ & Cukup & Baik & tidak layak & Layak \\
\hline 28 & 1955201252 & $\begin{array}{l}\text { ADINDA KHOIRUNNISA' } \\
\text { PUTRI WARDANI }\end{array}$ & Baik & Baik & Layak & Layak \\
\hline 29 & 1955201253 & $\begin{array}{l}\text { MUKHAMMAD SHOKIBUL } \\
\text { ILMI } \\
\end{array}$ & Cukup & Cukup & tidak layak & tidak layak \\
\hline 30 & 1955201256 & BUSTANUL HUDA & Baik & Baik & Layak & Layak \\
\hline 31 & 1955201258 & HISYAM AHMAD & Baik & Baik & Layak & Layak \\
\hline 32 & 1955201259 & $\begin{array}{l}\text { MUHAMMAD HIDAYAT } \\
\text { DZIKRUL GHOFILIN }\end{array}$ & Cukup & Baik & tidak layak & tidak layak \\
\hline 33 & 1955201260 & MUHAMMAD AFIFUDIN & Baik & Cukup & Layak & Layak \\
\hline 34 & 1955201261 & MOH FAJAR FALAH & Baik & Baik & Layak & Layak \\
\hline 35 & 1955201262 & KHORIDATUS SA'DIYAH & Baik & Baik & Layak & Layak \\
\hline 36 & 1955201265 & $\begin{array}{c}\text { MOCHAMMAD DANDIK } \\
\text { ARDIANSYAH } \\
\end{array}$ & Baik & Cukup & Layak & Layak \\
\hline 37 & 1955201266 & MAWARDI & Baik & Baik & Layak & Layak \\
\hline 38 & 1955201267 & $\begin{array}{c}\text { EKA FAISATUR } \\
\text { ROKHIMAH } \\
\end{array}$ & Baik & Baik & Layak & Layak \\
\hline 39 & 1955201269 & MIRANDA OKTAVIA & Baik & Baik & Layak & Layak \\
\hline 40 & 1955201270 & FITRI WULANDARI & Baik & Baik & Layak & Layak \\
\hline 41 & 1955201271 & ANIS FITRIA & Baik & Baik & Layak & Layak \\
\hline 42 & 1955201272 & $\begin{array}{c}\text { MUHAMMAD SANUSI } \\
\text { ALWI }\end{array}$ & Baik & Baik & Layak & Layak \\
\hline 43 & 1955201276 & ANGGA RIYAS ROSIDIN & Baik & Cukup & Layak & Layak \\
\hline 44 & 1955201277 & $\begin{array}{c}\text { NOVITA LAILATUS } \\
\text { SA'IDAH } \\
\end{array}$ & Baik & Baik & Layak & Layak \\
\hline 45 & 1955201278 & DEWI ANGGRAINI & Baik & Baik & Layak & Layak \\
\hline 46 & 1955201280 & ANISATUR ROCHMAH & Cukup & Baik & tidak layak & tidak layak \\
\hline 47 & 1955201281 & AHMAD HANAFI & Baik & Baik & Layak & Layak \\
\hline 48 & 1955201282 & $\begin{array}{l}\text { MUHAMMAD NAJA } \\
\text { MASKURI }\end{array}$ & Baik & Baik & Layak & Layak \\
\hline 49 & 1955201283 & HADI PRAYITNO & Baik & Baik & Layak & Layak \\
\hline 50 & 1955201284 & SITI KHAMIDAH & Baik & Baik & Layak & Layak \\
\hline 51 & 1955201285 & FERDILA AYU ARIESNA & Baik & Baik & Layak & Layak \\
\hline 52 & 1955201286 & DWI ARINI & Baik & Cukup & Layak & Layak \\
\hline 53 & 1955201287 & FIKA KUSNIA SARI & Baik & Cukup & Layak & Layak \\
\hline 54 & 1955201288 & RIVAL FADILLAH ZELDY & Baik & Baik & Layak & Layak \\
\hline 55 & 1955201289 & $\begin{array}{c}\text { MOHAMAD ALFIN } \\
\text { MAULANA } \\
\end{array}$ & Baik & Cukup & Layak & Layak \\
\hline 56 & 1955201293 & $\begin{array}{l}\text { AMELIA DWI RAMADHANI } \\
\text { SAFITRI } \\
\end{array}$ & Baik & Baik & Layak & Layak \\
\hline 57 & 1955201294 & $\begin{array}{c}\text { SHINTA NURIATUL } \\
\text { KHOFSOH } \\
\end{array}$ & Baik & Cukup & Layak & Layak \\
\hline 58 & 1955201297 & CAHYONO ADITYAWAN & Baik & Baik & Layak & Layak \\
\hline 59 & 1955201298 & DENY RESTYO NUGROHO & Baik & Baik & Layak & Layak \\
\hline 60 & 1955201299 & FANI ZUBAIDI ROSYID & Cukup & Cukup & tidak layak & tidak layak \\
\hline
\end{tabular}




\begin{tabular}{|c|c|c|c|c|c|c|}
\hline 61 & 1955201300 & LAYLATUL MAGHFIROH & Baik & Baik & Layak & Layak \\
\hline 62 & 1955201301 & $\begin{array}{c}\text { MUHAMMAD AINUL } \\
\text { YAQIN } \\
\end{array}$ & Baik & Baik & Layak & Layak \\
\hline 63 & 1955201302 & $\begin{array}{c}\text { MUHAMAD TAUFIQUR } \\
\text { RAHMAN } \\
\end{array}$ & Baik & Baik & Layak & Layak \\
\hline 64 & 1955201303 & $\begin{array}{l}\text { MUHAMMAD MISHBAHUL } \\
\text { KHOIR }\end{array}$ & Baik & Baik & Layak & Layak \\
\hline 65 & 1955201304 & RAFINES HANIFAH & Baik & Cukup & Layak & Layak \\
\hline 66 & 1955201305 & $\begin{array}{c}\text { AHMAD NAUFAL } \\
\text { RAMADAN } \\
\end{array}$ & Baik & Baik & Layak & Layak \\
\hline 67 & 1955201306 & $\begin{array}{c}\text { FASTA DELLA FITROTUL } \\
\text { HUSNAYAINI }\end{array}$ & Baik & Baik & Layak & Layak \\
\hline 68 & 1955201307 & $\begin{array}{c}\text { MOCHAMMAD IKHROM } \\
\text { ALFANDI }\end{array}$ & Baik & Cukup & Layak & Layak \\
\hline 69 & 1955201308 & MUHAMMAD TAUFIQ & Cukup & Cukup & tidak layak & tidak layak \\
\hline 70 & 1955201311 & $\begin{array}{c}\text { RISKY ROMADHON } \\
\text { ARDIANSYAH }\end{array}$ & Baik & Baik & Layak & Layak \\
\hline 71 & 1955201312 & ADITYA FEBRIANTO & Baik & Baik & Layak & Layak \\
\hline 72 & 1955201313 & NUR KHOMARIYAH & Baik & Baik & Layak & Layak \\
\hline 73 & 1955201314 & SITI RISMA ISNAFIYAH & Baik & Baik & Layak & Layak \\
\hline 74 & 1955201315 & $\begin{array}{l}\text { DWI NAHARANI } \\
\text { SHOLICHAH }\end{array}$ & Baik & Baik & Layak & Layak \\
\hline 75 & 1955201316 & MOH. ROMZI & Cukup & Cukup & tidak layak & tidak layak \\
\hline
\end{tabular}

Tabel 7 menjadi acuan dalam evaluasi sistem menggunakan confusion matrix yang hasilnya ditunjukkan pada Tabel 8 berupa true positif (TP), false positive (FP), false negatif $(\mathrm{FN})$ dan true negatif $(\mathrm{TN})$

Tabel 8. Confusion Matrix Skenario Ke-1

\begin{tabular}{|c|c|c|}
\hline & Data Layak & Data Tidak Layak \\
\hline $\begin{array}{c}\text { Penentuan Layak oleh } \\
\text { sistem }\end{array}$ & $\mathbf{6 0}(\mathrm{TP})$ & $\mathbf{1}(\mathrm{FP})$ \\
\hline $\begin{array}{c}\text { Penentuan Tidak Layak } \\
\text { oleh sistem }\end{array}$ & $\mathbf{5}(\mathrm{FN})$ & $\mathbf{9}(\mathrm{TN})$ \\
\hline
\end{tabular}

Tabel 5 menunjukkan evaluasi Confusion Matrix yang diperoleh dari data uji. Hasil yang diperoleh menggunakan algoritma naive bayes classifier adalah 60 data mahasiswa layak beasiswa PPA yang diprediksi benar (true positive), 9 data mahasiwa tidak layak beasiswa PPA yang diprediksi benar (true negative), 1 data mahasiswa tidak layak beasiswa PPA yang diprediksi layak (false positive), dan 5 data mahasiswa layak beasiswa PPA yang diprediksi tidak layak (false negative). Selanjutnya, dari hasil confision matrix terhadap 75 data, maka diperoleh evaluasi berupa accuracy dengan melakukan perhitungan yang ditunjukkan pada Persamaan 6, precission pada Persamaan 7 , dan recall pada Persamaan 8.

$$
\begin{aligned}
& \text { Accuracy }=\frac{60+9}{60+5+1+9}=\frac{69}{75}=0,92 \times 100 \%=92 \% \\
& \text { Precission }=\frac{60}{60+1}=\frac{60}{61}=0,98 \times 100 \%=98 \% \\
& \text { Recall }=\frac{60}{60+5}=\frac{60}{65}=0,923 \times 100 \%=92,3 \%
\end{aligned}
$$




\section{KESIMPULAN}

Penelitian ini berhasil mengimplementasikan algoritma naive bayes classifier untuk penentuan beasiswa peningkatan prestasi akademik (PPA) di Prodi Ilmu Komputer Universitas Nahdlatul Ulama Blitar dengan menggunakan 225 dataset yang terbagi atas 150 data latih dan 75 data uji. Dataset pada penelitian ini menggunakan dua atribut, yakni IPK Semester 1 dan IPK Semester 2. Sementara itu, kelas pada dataset terdiri atas kelas "layak" dan "tidak layak" dalam penentuan beasiswa PPA. Evaluasi sistem menunjukkan akurasi sebesar 92\%, presisi sebesar 98\% dan recall sebesar 92,3\%. Sebagai saran bagi penelitian yang akan datang, maka peneliti memberikan rekomendasi antara lain: 1) meningkatkan jumlah dataset; 2) melakukan proporsinonalitas dataset yang merata hingga seluruh prodi di Universitas Nahdlatul Ulama Blitar; 3) menambah nilai dan atribut pada dataset untuk meningkatkan objektifitas model naive bayes classifier.

\section{REFERENSI}

[1] A. Jaelani, "Klasifikasi Mahasiswa Penerima Beasiswa Dengan Metode Naive bayes," J. Chem. Inf. Model., vol. 53, no. 9, pp. 1689-1699, 2019.

[2] H. Sulistiani, "Penerapan Algoritma Klasifikasi Sebagai Pendukung Keputusan Pemberian Beasiswa Mahasiswa," in SNTI VI-2018 Universitas Trisakti, 2018, no. April, pp. 300-305, doi: 10.31227/osf.io/yuavj.

[3] A. E. Rahayu, K. Hikmah, N. Yustia, and A. C. Fauzan, "Penerapan K-Means Clustering Untuk Penentuan Klasterisasi Beasiswa Bidikmisi Mahasiswa," Ilk. J. Comput. Sci. Appl. Informatics, vol. 1, no. 2, pp. 82-86, 2019, doi: 10.28926/ilkomnika.v1i2.23.

[4] D. Dahri, F. Agus, and D. M. Khairina, "Metode Naive bayes Untuk Penentuan Penerima Beasiswa Bidikmisi Universitas Mulawarman," Inform. Mulawarman J. Ilm. Ilmu Komput., vol. 11, no. 2, p. 29, 2016, doi: 10.30872/jim.v11i2.211.

[5] R. A. Saputra and S. Ayuningtias, "Penerapan Algoritma Naive bayes Untuk Penentuan Calon Penerima Beasiswa Pada Smk Pasim Plus Sukabumi," Swabumi, vol. IV, no. 2, pp. 114-120, 2016.

[6] R. H. Dewi and N. Indrawati, "Rancang Bangun Sistem Pendukung Keputusan Penerimaan Beasiswa Menggunakan Meotde Naive bayes Classiffier," Semin. Nas. ke - 9 Rekayasa Teknol. Ind. dan Inf. Ranc., vol. 17, no. 3, pp. 79-84, 2014.

[7] I. Pangaribuan, "Penerapan Algoritma Naive bayes Untuk Seleksi Beasiswa Pemprov Dan Bawaku Di Universitas Komputer Indonesia Application of Naive bayes Algorithm for Selection of Providing and Bawaku Scholarship in University Computer Indonesia," 2019.

[8] T. Safitri, "Penerapan Algoritma Naïve Bayes Untuk Penentuan Calon Penerimaan Beasiswa Pada Sd Negeri 6 Ketapang," J. Inform. dan Sist. Inf., vol. 06, no. 01, pp. 43-52, 2020.

[9] C. Anam and H. B. Santoso, "Perbandingan Kinerja Algoritma C4.5 dan Naive bayes untuk Klasifikasi Penerima Beasiswa,” J. Ilm. Ilmu-Ilmu Tek., vol. 8, no. 1, pp. 13-19, 2018, [Online]. Available: https://ejournal.upm.ac.id/index.php/energy/article/view/111/449.

[10] D. Wahyuningsih and E. Patima, "Penerapan Naive bayes Untuk Penerimaan Beasiswa," Telematika, vol. 11, no. 1, p. 135, 2018, doi: 10.35671/telematika.v11i1.665. 